\title{
PUNIBILIDADE CONCRETA E POLÍTICA JUDICIÁRIA: \\ A PRESCRIÇÃO DA PRETENSÃO PUNITIVA ANTECIPADA E A GESTÃO DA JUSTIÇA
}

\section{Punishment and judicial policy: Limitations for advance punishment and for the management of justice}

\author{
Inayara Cabral de Souza'
}

Resumo: Este artigo é resultado de uma breve análise acerca da prescrição da pretensão punitiva antecipada e a gestão da justiça frente a aplicação da Súmula ${ }^{\circ} 438 /$ STJ e a atual política judiciária. A prescrição antecipada é criação da doutrina e jurisprudência brasileira e visa alcançar o prazo prescricional com fulcro em uma pena hipotética que venha a ser aplicada de acordo com as circunstâncias do
Abstract: This article is the result of a brief analysis about the prescription anticipated punitive intention and forward administering justice the application of Precedent n. 438 I STJ and the current judicial policy. Early prescription is creation of doctrine and jurisprudence Brazilian and aims to achieve the statute of limitations with fulcrum in a hypothetical penalty that may be applied according to the

1 Inayara Cabral de Souza. Bacharela em Direito pela Universidade da Região de Joinville (UNIVILLE). Pós-graduanda em direito público pela Universidade de Blumenau (FURB). Cursando os Módulo I (curso preparatório para a carreira da magistratura estadual) e Módulo III (Residência Judicial) da Escola Superior da Magistratura do Estado de Santa Catarina (ESMESC). Advogada, inscrita no quadro de advogados da OAB/SC sob o $n^{\circ} 39.394$ e Residente Judicial pelo Tribunal de Justiça de Santa Catarina, atuante na $1^{\text {a }}$ Vara Cível da Comarca de São Francisco do Sul, sob a orientação do Juiz de Direito Marlon Negri. E-mail: inayaracabraldesouza@gmail.com 
caso em concreto. Apesar de o STJ, por meio da Súmula $n^{\circ} 438$, vedar a aplicação da respectiva prescrição, vez que não definida por lei, a prescrição antecipada tem sido objeto de discussão entre os estudiosos do direito penal e processual penal, que pretendem a duração razoável do processo penal, para que este não se arraste durante anos para ao final não alcançar seu objetivo maior, a justiça. Assim este artigo visa uma breve apresentação sobre o surgimento da prescrição da pretensão punitiva e suas modalidades, explicitando o paradigma vigente no STJ, com base nos precedentes que deram ensejo à edição da Súmula $n^{\circ} 438 /$ STJ e, finalmente abordando os problemas de política judiciária que se relacionam com a referida súmula prospectando a melhor gestão da justiça e dos processos criminais com a aplicação da casualmente chamada 'prescrição antecipada'.

Palavras-chave: Prescrição antecipada. Súmula $n^{\circ} 438 /$ STJ. Pretensão punitiva. Política judiciária. Gestão da justiça. circumstances of the particular case. Although the Supreme Court by Precedent $n^{\circ} 438$, stopping the application of their prescription, since not defined by law, early prescription has been discussed among scholars of criminal law and criminal procedure, aimed at criminal proceedings to be completed in a reasonable time. So this article aims at a brief presentation on the theory of punitive intention, explaining the current paradigm in the Supreme Court, based on precedents that gave rise to the issue of Precedent $n^{\circ} 438$ / STJ and finally addressing the judicial policy issues that relate to the that summary prospecting better management of justice and criminal cases in the application of casually called 'early prescription'.

Keywords: Early prescription. Precedent $n^{\circ} 438$ / STJ. Claim punitive. Judicial policy. Management of justice.

\section{INTRODUÇÃO}

É inegável que o direito acompanha o movimento da sociedade e, a partir dela, desenvolve-se e amolda-se para melhor atender aos interesses dos indivíduos que daquela fazem parte. 
Assim devem ser, também, os órgãos do judiciário, que visando a melhor gestão da justiça devem acompanhar tal movimento para prestar uma tutela eficiente a seus jurisdicionados.

O tempo é fato relevante ao direito, e ao tratar-se de prescrição ele possui extrema relevância, uma vez que é a base para a aplicação da lei penal.

Dentro dessa concepção, levanta-se a discussão acerca da aplicação da prescrição da pretensão punitiva antecipada. Esta nada mais é que um instrumento capaz de aplicar a prestação jurisdicional com qualidade em um prazo razoável, com eficácia e eficiência, pautada em experiências semelhantes dos tribunais, de modo a promover a justiça e garantir a dignidade daqueles que necessitam do Poder Judiciário, fazendo com que este último atinja o cerne de sua existência.

Neste ponto, fixamos a base do estudo que levamos a feito com o presente artigo tendo por objetivos específicos a teoria do processo penal vinculada à política judiciária, analisando o conteúdo da Súmula no 438/ STJ que veda a aplicação da prescrição da pretensão punitiva antecipada por entender ser ela causadora de uma insegurança jurídica no processo penal e sua repercussão quanto à morosidade da "máquina judiciária" que poderia ser evitada ou ponderada com a aplicação do referido instituto.

\section{PRESCRIÇÃO DA PRETENSÃO PUNITIVA}

Antes de entrar no tema central deste artigo, imperiosa se faz uma breve análise do instituto da prescrição da pretensão punitiva no ordenamento jurídico vigente.

A prescrição da pretensão punitiva possui origem do termo latino praescriptio que deriva do verbo prescrever. Há notícia de sua existência no Direito Grego, porém só se consbstancia nos escritos do Direito Romano.

Tem-se, também, notícia que a prescrição penal surge com a lex Julia de adulteriis, no século XVIII a.C, em que ficou estabe- 
lecido o prazo de cinco anos para a prescrição dos crimes nela previstos - adultério, estupro e lenocínio. Nesse sentido Jawsnicker afirma:

Com o tempo, os romanos estenderam a prescrição para a generalidade dos demais delitos, excetuando o parricídio, apostasia e parto suposto. O prazo prescricional, foi alargado para vinte anos, mantida no entanto a prescrição qüinqüenal para os crimes previstos na lex Julia de adulteriis e para o peculato. ${ }^{2}$

É cediço, que o Direito Romano foi pioneiro e inspirou diversas legislações, a partir do seu conceito de prescrição. Ainda em Roma, a prescrição "se difundiu e tornou-se regra geral sobre a legislação imperial, sempre fixada no prazo de 20 anos". 3

Assim como a legislação Germânica, o Código de Instrução Criminal Francês incorporou ao seu ordenamento jurídico o instituto da prescrição, contudo, realizou algumas alterações nos prazos prescricionais previstos pela lei romana, variando seus prazos de acordo com a importância da condenação. Nesse sentido, Machado corrobora:

O Código de Instrução Criminal fez variar o prazo segundo a importância da condenação: 20 anos em matéria criminal, 5 anos em matéria correcional e 2 anos em matéria de simples política. $\mathrm{O}$ efeito desta prescrição era o de liberar apenas o condenado da execução material de sua pena, mas não da eficácia da condenação. ${ }^{4}$

No Brasil, falou-se pela primeira vez em prescrição no Código Criminal do Império de 1830, o qual dispunha em seu art. 65 acerca da não prescrição das penas, tranzendo a primeira concepção de imprescritibilidade penal, ensejando o entendimento de que poderia ocorrer a prescrição da ação penal.

2 JAWSNICKER, Francisco Afonso. Prescrição penal antecipada, p. 42.

3 MACHADO, Fábio Guedes de Paula. Prescrição penal: prescrição funcionalista, p. 87.

4 MACHADO, Fábio Guedes de Paula. Prescrição penal: prescrição funcionalista, p. 87. 
O Código de Processo Criminal Brasileiro de 1832 foi a primeira legislação penal brasileira a tratar da prescrição descrevendo sua ocorrência nos delitos e contravenções, onde entendia-se que para haver a prescrição haveria uma negligência do poder público quanto ao seu direito-dever de punir.

Nas legislações penais e processuais penais posteriores, verifica-se a mesma fundamentação, sofrendo pequenas alterações no que diz respeito aos prazos, datas de início e causas suspensivas e interruptivas da prescrição.

Com a chegada do Código Penal (CP), de 1940, vigente até os dias atuais, é que a matéria foi devidamente regulamentada e inseriu-se no ordenamento jurídico brasileiro a prescrição no item descrito como 'extinção da punibilidade'.

Atualmente, a prescrição é uma das modalidades de extinção da punibilidade arroladas pelo art. 107 do CP, mais precisamente em seu inciso IV, sendo ela, também, tratada pelo respectivo diploma legal do art. 109 ao art. 119.

À luz do entendimento doutrinário penalista, entende-se a prescrição penal como sendo a perda do jus persequendi in judicio ou do jus puniendi em razão do decurso do tempo. Nesse sentido, Dotti assevera:

A prescrição é uma das formas de extinção da punibilidade pelo decurso do tempo. A passagem do tempo apaga a lembrança dos fatos fazendo com que o crime caia no esquecimento de maneira a cessar o alarma e o desiquilíbrio social por ele causado. ${ }^{5}$

A prescrição poderá ocorrer antes ou após o trânsito em julgado da decisão penal, ora atingirá a pretensão punitiva da ação penal, ora alcançará a pretensão executória do Estado. Assim, também entende Damásio de Jesus: "Prescrição penal é a perda do poder-dever de punir do Estado pelo não exercício da pretensão punitiva ou da pretensão executória durante um certo tempo". ${ }^{6}$

5 DOTTI, René Ariel. Curso de direito penal, p. 771.

6 JESUS, Damásio Evangelista de. Prescrição penal, p. 17. 
É de se salientar, que a prescrição penal é matéria de ordem pública, assim deverá ser declarada de ofício pelo juiz assim que constatada a sua ocorrência, podendo ela ser declarada a qualquer tempo e grau de jurisdição. Nessa toada, o art. 61 do CP, dispõe: "Em qualquer fase do processo, o juiz, se reconhecer extinta a punibilidade, deverá declará-lo de ofício".?

Assim, a prescrição penal surge e encontra fundamentos no interesse do Estado em resolver as relações jurídicas penais, a ponto de não deixar suspensas essas relações por tempo indeterminado, de modo a evitar a desordem, a impunidade e a injustiça.

\section{PRESCRIÇÃODAPRETENSÃOPUNITIVAANTECIPADA}

A prescrição antecipada se trata de uma construção doutrinária e jurisprudencial recente, que por sua vez surgiu dos anseios por uma justiça capaz de resolver determinadas situações em prazos razoáveis e de forma compatível com o desejo popular.

Pode-se dizer que o instituto em tela surgiu essencialmente a partir da preocupação de membros do Ministério Público e Juízes de primeira instância, que ao perceberem a excessiva quantidade de processos em seus gabinetes, bem como a demora do judiciário em julgá-los, visualizaram a possibilidade de aplicação desse novo instituto, a fim de buscar maior celeridade e economia, tanto de tempo quanto de recursos, no julgamento das ações penais.

Em razão de tantas manifestações conflituosas acerca de sua aplicabilidade a matéria foi pacificada pelo STJ, por meio da edição da Súmula no 438 , no sentido de inadmitir tal instituto na modalidade antecipada.

Contudo, ainda, surgem embates acerca de sua aplicação, tendo em vista que muitos operadores do direito se utilizam desse instituto.

7 BRASIL. Código de processo penal. Lei n Decreto-lei n 3.689 , de 3 de outubro de 1941. Aprova o código de processo penal. 
O instituto da prescrição ao ser estudado com certa profundidade nos apresenta que o estigma do 'privilégio da legislação' inexiste, fazendo-se necessário e essencial ao ordenamento jurídico por fazer o controle do direito de punir estatal.

Dentro deste contexto, incerto e controvertido, surge a prescrição antecipada, modalidade de prescrição da pretensão punitiva que ainda não foi recepcionada pelo Código Penal Brasileiro.

Tomando por base a lacuna legal, a jurisprudência dos tribunais afirma que não será cabível a aplicação da prescrição penal em sua modalidade antecipada. Haverá apenas a prescrição pela pena in concreto, ou seja, quando a sentença transitar em julgado para a acusação ou na sua modalidade retroativa no período compreendido entre o recebimento da denúncia ou queixa e a sentença condenatória recorrível. Nesse sentido, colhe-se do julgado do Ministro Vidigal:

PENAL. PROCESSUAL. DENÚNCIA. INÉPCIA. DOLO ESPECÍFICO. DILAÇÃO PROBATÓRIA. PRESCRIÇÃO ANTECIPADA. HABEAS CORPUS. RECURSO.

Não há que se falar em inépcia da denúncia quando esta preenche os requisitos do Código de Processo Penal, art. 41, garantindo, ao acusado, o direito à ampla defesa. $\mathrm{O}$ habeas corpus não se presta ao exame de provas, matéria afeta ao contraditório próprio da instrução criminal. Nosso ordenamento jurídico- processual não contempla a prescrição por antecipação. Pretensão recursal que carece de amparo legal. Recurso a que se nega provimento. ${ }^{8}$

Porém o argumento de falta de previsão legal é refutado por parte da doutrina e jurisprudência que entende não haver hierarquia entre os princípios no ordenamento jurídico brasileiro, sendo assim o reconhecimento e aplicação do referido instituto deveria prosperar perante o critério da razoabilidade.

8 BRASIL. Superior Tribunal de Justiça. Recurso em Habeas Corpus n. 8274 ES 1999/0004613-7. Rel. Des. Edson Vidigal, j. 13 de setembro de 1999. 
Mas, tomando como ponto de partida a norma positivada, conclui-se que a prescrição antecipada não existe no ordenamento jurídico brasileiro, logo não poderia ser aplicada.

\subsection{A Prescrição Antecipada como causa da extinção da punibilidade}

Como já afirmado ao longo deste trabalho, a prescrição antecipada leva em conta a pena hipotética a ser aplicada a cada caso concreto.

Ainda que a questão tenha sido pacificada pelo STJ por meio da Súmula no 438, objetivando inadmissível a aplicação do instituto ora estudado, muitas são as discussões doutrinárias e jurisprudenciais acerca do tema, isso porque existem inúmeros argumentos favoráveis e contrários a sua aplicação.

Assim, tratar-se-á a seguir de todas as questões principiológicas constitucionais e processuais que norteiam o tema.

\subsubsection{Argumentos contrários à prescrição antecipada}

O entendimento majoritário da doutrina e dos Tribunais brasileiros rejeita a aplicação dessa modalidade prescricional sob inúmeros argumentos, que se contrapõem aos argumentos favoráveis à aplicabilidade desse instituto pela corrente minoritária.

\subsubsection{Falta de amparo legal}

Argumento utilizado pela maior parte da jurisprudência, a falta de amparo legal em nosso ordenamento jurídico, funda-se nos Códigos Penal e de Processo Penal Brasileiro que não contemplam de maneira expressa a prescrição antecipada. Nesse sentido, Almeida afirma:

Dentre os argumentos contrários à aceitação da prescrição retroativa antecipada, ressalta-se a falta de amparo legal, posto que o art. $110, \S \S 1^{\circ}$ e $2^{\circ}$, do Código Penal, prevê que a prescrição 
retroativa pressupõe a existência de uma sentença penal condenatória. Não havendo lei nesse sentido, a aceitação dessa espécie de prescrição constituiria uma ofensa ao princípio da legalidade. ${ }^{9}$

Assim, não havendo nenhum dispositivo que reze que a prescrição antecipada subtrai a justa causa e o interesse de agir da ação penal, esta será inadmissível.

No entanto, os militantes favoráveis à aplicação dessa modalidade prescricional entendem que não é a falta de previsão legal expressa que afasta a aplicação do instituto e sua existência. Sob essa análise, Nunes afirma que a prescrição antecipada:

Visa justamente homenagear a magna garantia do devido processo legal, notadamente em seu prisma substancial que, como visto, descansa no princípio da razoabilidade. [...] Isso porque não é razoável, quando possível antever seguramente o patamar da sanção, a propositura da ação penal para que ao final, preclusa a faculdade recursal da acusação ou desprovido seu recurso, se constate que o direito de punir foi fulminado pelo decurso do tempo. ${ }^{10}$

Verifica-se que o desconhecimento ou confusão do significado da prescrição antecipada leva a discussão para um rumo diferente do esperado, visto que para uma parte dos operadores do Direito que debatem a prescrição antecipada esta não seria mais um meio de extinção da punibilidade que ocorre em razão do decurso do tempo tão simplesmente, mas estaria sedimentada na falta de condições da ação penal, quais sejam: justa causa e interesse de agir.

\subsubsection{Violação ao princípio do dueprocessoflaw e o direito do acusado a uma sentença de mérito}

O princípio do devido processo legal tem previsão no art. 5\%, inciso LIV, da Constituição Federal, in verbis: "ninguém será

9 ALMEIDA, Thiago Bockie de. Quais os argumentos contrários e favoráveis à aplicação da prescrição retroativa antecipada?,p. 23.

10 NUNES, Ricardo Pieri. Considerações em abona do reconhecimento antecipado da prescrição retroativa, p. 11. 
privado da liberdade ou de seus bens sem o devido processo legal", ${ }^{11}$ que reúne em seu conceito outras garantias processuais constitucionais, tais como o contraditório, a ampla defesa e a exigência de um juiz natural para a causa.

O referido princípio revela uma garantia processual a ser usada pelo acusado em face do Estado, com o intuito de impedir o abuso de poder pela autoridade detentora do jus puniendi no curso da ação penal.

Segundo parte da doutrina e jurisprudência que resistem ao reconhecimento desta modalidade prescricional a aplicação da prescrição antecipada geraria um dano inestimável ao acusado uma vez que feriria sua garantia constitucional ao devido processo legal, bem como reconheceria sua culpa ou dolo condenando-o previamente sem análise do mérito da causa. Nesse sentido, corrobora Souza:

Uma distinta corrente entende incabível a prescrição antecipada porque a previsão da pena revela análise de mérito sem o devido processo legal, princípio mundialmente consagrado, e sem o devido contraditório, o que é vedado no processo penal brasileiro, concluindo que a análise do interesse de agir não pode ser profunda e confundir-se com a análise de mérito. ${ }^{12}$

Razão assiste a esse entendimento no que tange à apreciação do mérito para a aferição da pena. De outro vértice, este argumento não passa de mera análise superficial, visto que o simples arquivamento do inquérito policial enseja uma análise superficial das provas, o que faz válida a argumentação favorável à aplicação da prescrição antecipada, derrubando o suprarreferido argumento contrário a esta.

11 BRASIL. Constituição (1988). Constituição da República Federativa do Brasil. 12 SOUZA. Renée. Prescrição virtual ou antecipada, p. 50. 


\subsubsection{Violação aos princípios do contraditório e da ampla defesa}

No que tange ao princípio do contraditório, consubstanciado no ordenamento jurídico brasileiro no art. $5^{\circ}$, inciso LV, da Constituição Federal, in verbis: "aos litigantes, em processo judicial ou administrativo, e aos acusados em geral são assegurados o contraditório e ampla defesa, com os meios e recursos a ela inerentes", ${ }^{13}$ pode-se afirmar se tratar de princípio fundamental ao direito processual penal.

Tal princípio estabelece que deverá ser oportunizando ao acusado uma reação da defesa para cada informação apresentada pela acusação no curso da ação penal, assim o processo penal deverá ser conduzido de maneira dialética.

$\mathrm{Na}$ visão daqueles que acreditam ser inadmissível a aplicação da prescrição antecipada, este princípio constitucional estaria sendo violado, visto que na medida em que fosse permitida a aplicação da prescrição retroativa antecipada, não haveria como o Magistrado (ou o Ministério Público) prever se a sentença será ou não condenatória. Nesse sentido, Almeida afirma:

A adoção dessa tese prescricional resultaria em uma prévia condenação do agente, com o prejulgamento de um fato do qual não foi feita prova em juízo. Além de se prever uma sentença condenatória, a pena, hipoteticamente considerada, é fundada em dado aleatório, não condizente com o Direito..$^{14}$

Contudo, como já vislumbrado anteriormente não há que se falar em sentença condenatória tendo em vista que a análise é meramente superficial com o intuito de prever aproximadamente a pena que seria aplicada ao caso concreto, não sendo proferida sentença de resolução de mérito, de modo tal que não seria ferido o princípio do contraditório.

13 BRASIL. Constituição (1988). Constituição da República Federativa do Brasil. 14 ALMEIDA, Thiago Bockie de. Quais os argumentos contrários e favoráveis à aplicação da prescrição retroativa antecipada?,p. 25. 
Ademais, deve-se ainda falar do princípio da ampla defesa que tal qual o princípio do contraditório trata-se de garantia constitucional (art. 5\%. LV, CRFB).

Tal princípio possibilita a efetiva participação do acusado no processo penal, com a elaboração de defesa técnica feita por pessoa regularmente habilitada nos autos (advogado ou defensor público), bem como proporciona ao acusado a oportunidade deste falar sobre os fatos que lhe são (autodefesa). Sob essa análise, Oliveira corrobora:

Enquanto o contraditório exige a garantia de participação, o princípio da ampla defesa pressupõe uma realização efetiva desta participação, sob pena de nulidade, também quando prejudicial ao acusado. ${ }^{15}$

Contudo, em contraposição a este entendimento os defensores do instituto afirmam não existir ofensa ao direito da ampla defesa e ao contraditório, posto que tais princípios nascem a partir do exercício do direito de ação e no caso da prescrição antecipada tal direito não poderia ser exercido em razão da ausência de interesse de agir.

\subsubsection{Violação à presunção de inocência}

Outro ponto desfavorável à aplicação da prescrição antecipada é a alegação de que tal modalidade prescricional violaria o princípio da presunção da inocência.

Tal princípio, enunciado no art. $5^{\circ}$, inciso LVII, da CRFB, assegura ao acusado o direito de ter um provimento jurisdicional que reconheça sua inocência, ao passo que dita que ninguém será considerado culpado até o trânsito em julgado de sua sentença condenatória.

Com isso, os opositores do instituto da prescrição antecipada fundam-se na impossibilidade de alguém ser pré-julgado como culpado para fins de reconhecimento da prescrição. Logo, seria a prescrição antecipada contrária a mandamento constitucional, tendo em vista que seu reconhecimento apenas se daria

15 OLIVEIRA, Eugênio Pacelli de. Curso de Processo Penal, p. 24. 
se reconhecida fosse a condenação do acusado. Nesse sentido, Almeida ratifica:

Dentre os adeptos da corrente majoritária, alguns entendem que a prescrição retroativa antecipada presume um estado de culpabilidade do sujeito, antevendo-o como responsável pela prática da infração penal, o que implicaria em violação ao estado de inocência do réu. ${ }^{16}$

De outro vértice, parte da doutrina, ainda que minoritária, entende que o reconhecimento da prescrição virtual não violaria o princípio da presunção de inocência, visto que sequer será reconhecida e sentenciada a condenação do acusado. De acordo com esse entendimento, afirma Serpa:

Na verdade, o magistrado, verificando uma possivel condenação (até porque ausentes os indícios de autoria estaria obstada a ação penal, por ausência de justa causa), antecipa seu raciocínio para verificar, de plano, qual a maior pena possível de ser aplicada no caso concreto apresentado, dentro do critério da individualização da pena. ${ }^{17}$

Razão assiste a parte da doutrina que afirma que a sentença, que virtualmente será trabalhada para o reconhecimento da prescrição antecipada, terá cunho condenatório. Contudo, isso não implicará no real reconhecimento da culpabilidade do acusado, visto que não haverá sentença, menos ainda sentença condenatória, posto que se considera, nessas situações, a carência da ação penal.

\subsubsection{Violação aos princípios da obrigatoriedade e indisponibilidade da ação penal}

O princípio da obrigatoriedade da ação penal determina que o Ministério Público tem o dever institucional de promover

16 ALMEIDA, Thiago Bockie de. Quais os argumentos contrários e favoráveis à aplicação da prescrição retroativa antecipada?,p. 28.

17 SERPA, Juliano. A prescrição penal antecipada como causa de extinção da punibilidade no direito penal brasileiro, p.165. 
a ação penal pública quando houver justa causa, "não podendo utilizar, portanto, aspectos discricionários (conveniência e oportunidade) para não denunciar e fundamentar eventual arquivamento dos autos do inquérito policial”. ${ }^{18}$

Já o princípio da indisponibilidade da ação penal informa que o Ministério Público não pode dispor/desistir da ação penal uma vez proposta.

Tão logo, o argumento contrário à prescrição antecipada que se firma ensina que desde que formada a opiniodelict não pode o Ministério Público por critérios de conveniência e oportunidade, deixar de exercitar a ação penal e, uma vez esta exercitada não pode do mesmo modo o Parquet dispor da ação, "competindo ao juiz velar por este exercício compulsório". ${ }^{19}$

De outra monta, parte da doutrina entende ser este argumento carente de fundamentação, visto que antes da opiniodelict deve ser analisada a existência das condições da ação. Ausente uma delas, afastada estará a obrigatoriedade da ação e o dever de agir.

\subsubsection{6 Óbice à emendatiolibelli e mutatiolibelli}

O instituto da emendatiolibelli está definido no art. 383 do Código de Processo Penal, in verbis: "Art. 383. O juiz poderá dar ao fato definição jurídica diversa da que constar da queixa ou da denúncia, ainda que, em consequência, tenha de aplicar pena mais grave." ${ }^{20}$

Já o instituto da mutatiolibelli, por sua vez, tem previsão no art. 384 do Código de Processo Penal nos seguintes termos:

Art. 384. Se o juiz reconhecer a possibilidade de nova definição jurídica do fato, em consequência de prova existentes nos autos de circunstância elementar, não contida, explícita ou implici-

18 ALMEIDA, Thiago Bockie de. Quais os argumentos contrários e favoráveis à aplicação da prescrição retroativa antecipada?,p. 30.

19 SOUZA. Renée. Prescrição virtual ou antecipada, p.49.

20 BRASIL. Código de processo penal. Decreto-lei 3.689, de 03 de outubro de 1941. Aprova o código de processo penal. 
tamente, na denúncia ou na queixa, baixará o processo, a fim de que a defesa, no prazo de 8 (oito) dias, fale e, se quiser, produza prova, podendo ser ouvidas até três testemunhas.

Parágrafo único. Se houver possibilidade de nova definição jurídica que importe aplicação de pena mais grave, o juiz baixará o processo, a fim de que o Ministério Público possa aditar a denúncia ou queixa, se em virtude desta houver sido instaurado o processo em crime de ação pública, abrindo-se, em seguida, o prazo de 3 (três) dias à defesa, que poderá oferecer prova, arrolando até três testemunhas. ${ }^{21}$

Ao passo em que se trata dos institutos da mutatiolibelli e da emendatiolibelli, necessária se faz a análise do princípio processual da correlação, no qual o Magistrado não deve julgar além da demanda delimitada na denúncia, estando ele vinculado a decidir de acordo com os fatos narrados e não ao dispositivo legal listado pelo Parquet.

Por essa razão, criadas foram as figuras da mutatiolibellie da emendatiolibelli, para que se possa sanar capitulação legal constante na denúncia ou queixa.

Com relação à aplicação da prescrição antecipada, verifica-se que parte da doutrina e jurisprudência entendem que, uma vez aplicado, este instituto seria inviabilizado o reconhecimento da emendatiolibelliou da mutatiolibelli, "visto que dependendo do estado de instrução em que ele se encontre, a produção de provas não terá sido suficiente para a alteração da definição legal inserta na peça exordial acusatória”.22

Ainda, ressalta parte da doutrina que eventual mudança de definição legal poderia resultar em diferença substancial do prazo prescricional, o que impediria a extinção da punibilidade, inclusive com fundamento na prescrição antecipada.

21 BRASIL. Código de processo penal. Decreto-lei 3.689, de 03 de outubro de 1941. Aprova o código de processo penal.

22 ALMEIDA, Thiago Bockie de. Quais os argumentos contrários e favoráveis à aplicação da prescrição retroativa antecipada?,p. 30. 
Pertinente é a tese acima mencionada, contudo insuficiente para afastar de modo definitivo a modalidade prescricional antecipada, isso porque a prescrição antecipada poderá ocorrer antes mesmo do oferecimento da denúncia ou queixa ainda na fase inquisitiva e não apenas durante o curso processual.

\subsubsection{Argumentos favoráveis à prescrição antecipada}

Parte da doutrina e jurisprudência brasileiras entende como cabível e, às vezes, até necessária, a adoção da prescrição antecipada, arrolando alguns argumentos favoráveis à sua utilização.

\subsubsection{Falta de interesse de agir e justa causa}

Talvez o maior argumento para a aplicação da prescrição antecipada, revelado pelos doutrinadores seja o interesse de agir e a justa causa. Isso porque esses dois elementos fazem parte das condições essenciais para a propositura da ação penal.

$\mathrm{O}$ interesse de agir consiste no interesse de quem necessita ir a Juízo para a obtenção de uma prestação por parte do Poder Judiciário.

Ao passo que a justa causa consubstancia-se no próprio interesse de agir e nas demais condições da ação e condições de procedibilidade para a propositura da ação penal.

Como esses dois institutos são muito próximos e, por vezes, se confundem, é de se ressaltar que ainda que exista a justa causa para a acusação, poderá não haver o legítimo interesse de agir, decorrendo assim, o interesse de agir da pretensão penal condenatória.

O interesse de agir consiste basicamente no binômio necessidade-adequação, contudo parte da doutrina ainda ressalta que o interesse de agir consistiria num trinômio, qual seja: necessidade, utilidade e adequação. 
Quanto ao interesse-utilidade fato é que este só existe se houver ao menos uma expectativa de concretização do jus puniendi, com a consequente fixação da sanção penal.

Partindo dessa premissa, funda-se a tese defensora da prescrição antecipada, tendo em vista que "a falta do interesse de agir acarreta a ausência de justa causa para o prosseguimento da ação penal”. ${ }^{23}$

Assim, qualquer ação que se demonstrar desnecessária e inútil considerando que a sanção visada jamais será efetivamente aplicada ou porque este fim não poderá mais ser materialmente realizado em razão do decurso do tempo, faltará interesse de agir, visto que esta jamais conseguirá atingir sua finalidade. Logo, deverá a ação ser extinta sem julgamento do mérito por ser carecedora da condição fundamental da ação. Nesse sentido, Coutinho salienta:

Pode-se afirmar que não é porque a lei não prevê expressamente a prescrição virtual, que a mesma [sic] não pode ser alcançada por meio de uma interpretação sistemática ou finalista, facilmente é de se notar que nas hipóteses de prescrição antecipada, induz falta de interesse de agir para o prosseguimento da ação penal. ${ }^{24}$

Dessa forma, se de plano for possível visualizar a inutilidade da ação penal, inexistirá o interesse de agir, visto que "o interesse processual é uma relação de necessidade e uma relação de adequação, porque seria inútil a provocação da máquina estatal se ela não for apta a produzia a punição do autor do ilícito". ${ }^{25}$

Em suma, não há necessidade, nem adequação e menos ainda utilidade em dar início a um processo penal ou, ainda, dar continuidade a instrução criminal, quando já se prevê, que

23 ALMEIDA, Thiago Bockie de. Quais os argumentos contrários e favoráveis à aplicação da prescrição retroativa antecipada?,p. 30.

24 COUTINHO, Jacinto Nelson de Miranda. A lide e o conteúdo do processo penal. 25 SERPA, Juliano. A prescrição penal antecipada como causa de extinção da punibilidade no direito penal brasileiro, p. 165. 
inevitavelmente, a sanção penal não poderá ser aplicada, pois já estaria extinta pela ocorrência da prescrição retroativa. É neste ponto que ocorre o reconhecimento da prescrição antecipada, quando, no curso da ação penal, percebe-se que imperiosa é a incidência dessa modalidade prescricional, tomando-se por base a pena que possivelmente seria aplicada.

\subsubsection{Instrumentalidade do processo (economia processual e efetividade da tutela jurisdicional)}

Além da falta do interesse de agir, a prescrição antecipada encontra amparo no princípio da economia processual e na efetividade da tutela jurisdicional, pois, além de dispendioso para o Estado, seria um desperdício temporal submeter alguém a um processo criminal que, ao final, será absolvido pelo advento da prescrição ou, ainda, dar prosseguimento ao feito, em prejuízo de outros processos, gerando esforços inúteis que serão confrontados com a prescrição retroativa.

Compreende-se por economia processual o conjunto de esforços aplicados na tentativa de se evitar o desperdício de tempo e recursos, na condução dos processos, bem como dos atos processuais. Nesse sentido, o Tribunal Regional Federal da 4a Região fundamentou a adoção excepcional da prescrição antecipada em razão do princípio da instrumentalidade processual:

Como regra, não se pode chancelar a decretação da prescrição em concreto com base na pena que futuramente iria ser aplicada ao acusado, já que essa modalidade é estranha ao Direito Penal pátrio. No caso concreto, ainda que típica a conduta, tendo em vista as peculiaridades presentes, deve-se reconhecer esta modalidade de prescrição, em homenagem ao princípio da instrumentalidade do processo. $^{26}$

26 BRASIL. Tribunal Regional Federal da $4^{\text {a }}$ Região. Recurso em Sentido Estrito 199.70.01.008573/5. Rel. Des. Wolkmer de Castilho, j. 07 de outubro de 2002. 
Assim, o reconhecimento da prescrição antecipada atende de maneira extraordinária o princípio da economia processual, visto que inútil e desnecessário o ajuizamento e a continuidade de uma ação penal que em nada resultará.

Mais além, pode-se perceber que o argumento econômico não está limitado ao princípio da economia processual, mas trata-se também de "um meio de se evitar desperdício de recursos públicos e, em consequência, atende ao importante princípio da moralidade administrativa”. ${ }^{27}$

Dessa forma, os defensores da prescrição antecipada, encontram respaldo suficiente no argumento da economia processual, haja vista a total desnecessidade e inutilidade de movimentar-se a máquina estatal, na apuração de um processo em que já se sabe que em lugar algum se chegará.

\subsubsection{Princípio da dignidade da pessoa humana e a penalização do réu pela morosidade da justiça}

O princípio da dignidade da pessoa humana foi consubstanciado pela CRFB de $1988 \mathrm{em}$ seu art. $1^{\circ}$, inciso III, que reconhece a dignidade da pessoa humana como fundamento do Estado democrático de direito, bem como uma prerrogativa de todo ser humano de não ser prejudicado em sua existência. Nesse Sentido, assevera Moraes:

A dignidade é um valor espiritual e moral inerente à pessoa, que se manifesta singularmente na autodeterminação consciente e responsável da própria vida e que traz consigo a pretensão ao respeito por parte das demais pessoas, constituindo- se em um mínimo invulnerável que todo estatuto jurídico deve assegurar, de modo que, somente excepcionalmente, possam ser feitas limitações ao exercício dos direitos fundamentais, mas sempre sem menosprezar a necessária estima que merecem todas as pessoas enquanto seres humanos. ${ }^{28}$

27JAWSNICKER, Francisco Afonso. Prescrição penal antecipada, p. 42 28 MORAES, Alexandre de. Constituição do Brasil interpretada e a legislação cons- 
Adotar a dignidade da pessoa humana como valor básico do Estado democrático de direito é prerrogativa de o valor absoluto do ponto de vista constitucional.

Esse princípio se tornou uma barreira irremovível na defesa dos direitos humanos e é forte argumento para a aplicação da prescrição antecipada uma vez que um longo e inútil processo penal cria para o acusado um estigma que o acompanhará até a resolução da ação penal ou talvez a vida toda, sendo este penalizado pela morosidade da justiça.

Conforme a lição de Zaffaroni, o sistema penal é mantido por meio da seleção vitimizante e a vulnerabilidade das pessoas desvaloradas pela sociedade. Para ele, o Direito Penal subjetivo, ou como denomina, a criminalização secundária seleciona, inevitavelmente, o figurino social dos delinquentes, sob orientação burocrática. ${ }^{29}$

Ademais, é notória a interferência do processo penal existente na vida pessoal do acusado, pois o estigma a ele empregado causa um exorbitante constrangimento, que à luz do princípio da dignidade humana é um constrangimento ilegal na vida do mesmo, ainda mais quando provável o reconhecimento da prescrição antecipada. Com efeito, Brandão afirma que "é evidente o constrangimento a que está sujeito o réu, que aguardará por longos meses seu julgamento para que, mesmo se condenado for, somente então se possa ter a prescrição reconhecida". ${ }^{30}$

Ainda, revela-se inútil a continuidade de um processo que jamais atingirá sua finalidade, pois será de uma forma ou de outra, fulminado pelo instituto da prescrição.

A prescrição antecipada mostra-se medida mais vantajosa por diversos aspectos. Ao acusado, traduz-se na diminuição do martírio processual a ele causado, como se fosse um meio de diluir o estigma a ele imputado em razão da ação penal. Nesse diapasão, Fernandes leciona que: 
[...] submeter alguém aos dissabores de um processo penal, tendo a certeza de que será inútil, constitui constrangimento ilegal, uma vez que a mesma injustiça, decorrente da acusação posta sem que seja possível antever condenação do réu, existe quando não há possibilidade de cumprimento da sentença condenatória porque será alcançada pela prescrição. ${ }^{31}$

Perceptível é que o direito estatal de punir somente tem razão quando a sentença condenatória for capaz de cumprir sua finalidade, atendendo de maneira eficaz os postulados do Estado democrático de direito, bem como o princípio da dignidade da pessoa humana. Nesse prisma, Machado verbera que:

Pela perda do valor simbólico do fato cometido e de sua consequente penalização pelo transcurso do tempo, materializado pelo desaparecimento da necessidade da pena, qualquer processo penal em trâmite ou futura imposição de condenação que não redundará na efetiva aplicação da lei penal constitui-se como atentado à dignidade humana. ${ }^{32}$

Por fim, é possível concluir que o desenvolvimento do processo penal fadado ao insucesso não atende ao princípio da dignidade da pessoa humana, servindo nesses casos tão-somente como instrumento de estigmatização social. Conforme Silva,

a dignidade da pessoa humana não é uma criação constitucional, pois ela é um desses conceitos a priori, um dado preexistente a toda experiência especulativa, tal como a própria pessoa humana. Por isso, ela [...] não estará assegurada se o indivíduo é humilhado, discriminado, perseguido ou depreciado. ${ }^{33}$

Esses são, portanto, alguns argumentos da doutrina e jurisprudência que aceitam ou rejeitam a aplicação da prescrição retroativa antecipada.

31 FERNANDES, AntonioScarance. A provável prescrição retroativa e a falta de justa causa para a ação penal, p. 38-43.

32 MACHADO, Fábio Guedes de Paula. Prescrição penal: prescrição funcionalista, p. 163.

33 SILVA, José Afonso da.Curso de direito constitucional positivo, p. 95. 


\section{A PRESCRIÇÃO ANTECIPADA E A LEI n $12.234 / 2010$}

A Lei $n^{\circ} 12.234 / 2010$ promoveu algumas alterações nos arts. 109 e 110 do CP, alterações essas que produziram reflexos importantes na contagem dos prazos prescricionais, de modo especial em suas modalidades retroativa e antecipada.

As alterações realizadas repercutem especialmente na sistemática de contagem do prazo prescricional ampliando de certo modo o lapso temporal para que o Estado apure as infrações penais e tome as medidas cabíveis ao caso concreto.

Outras alterações foram promovidas pela nova Lei tais como: a modificação na incidência da prescrição retroativa que com a nova redação legal tornou impossível computar qualquer tempo antes do recebimento da denúncia ou queixa, fazendo com que essa modalidade de a prescrição só ocorra entre o recebimento da denúncia ou queixa e a publicação da sentença.

Acerca dessa alteração, alguns doutrinadores entendem que a modalidade de prescrição penal retroativa foi extinta. Contudo, o entendimento majoritário é de que foi extinta apenas a primeira possibilidade da ocorrência da prescrição retroativa, subsistindo ainda a possibilidade de sua ocorrência no período compreendido entre o recebimento da denúncia e a sentença penal condenatória recorrível. Isso porque assim determina a redação do art. 20 da Lei no 12.234/10:

§1 $1^{\circ}$ A prescrição, depois da sentença condenatória com trânsito em julgado para a acusação ou depois de improvido seu recurso, regula-se pela pena aplicada, não podendo, em nenhuma hipótese, ter por termo inicial data anterior à denúncia ou queixa. ${ }^{34}$

Posto isso, no que tange a prescrição antecipada como sempre foi atrelada à prescrição retroativa, também foi cortada pela metade. Segundo o que prevê a nova redação dada ao art. 110, do CP, apenas será possível a ocorrência da prescrição retro-

34 BRASIL. Lei $n^{\circ}$ 12.243, de 05 de maio de 2010. Altera os arts. 109 e 110 do Decreto-Lei no-2.848, de 7 de dezembro de 1940 - Código Penal. 
ativa entre o recebimento da denúncia ou queixa e a sentença penal condenatória recorrível, tão logo a prescrição antecipada também só será possível agora entre a data do recebimento da denúncia ou queixa e a publicação da sentença.

Há de se ressaltar que esta Lei gera uma situação jurídica mais gravosa ao acusado, assim aos crimes praticados antes da vigência da referida Lei, ou seja, crimes anteriores à data de 6 de maio de 2010, ainda será possível a aplicação da prescrição retroativa. Nesse sentido, ensina Galvão:

\begin{abstract}
A extinção do instituto da prescrição retroativa, determinada pelo art. 10 da Lei ${ }^{\circ} 12.234$, constitui situação jurídica mais gravosa ao condenado e, tendo em vista o disposto no inciso XL do art. $5^{\circ}$ da Constituição Federal da República, tal restrição somente se aplica aos fatos ocorridos posteriormente a entrada em vigor da referida lei. Dessa forma, não é possível impedir a aplicação da prescrição retroativa aos fatos ocorridos anteriormente a entrada em vigor da lei penal mais gravosa, pois a lei penal não retroagirá, salvo para beneficiar o réu. Como a lei entrou em vigor na data de sua publicação, ocorrida no dia 6 de maio de 2010, aos fatos anteriores a esta data pode-se aplicar a prescrição retroativa da pretensão punitiva. ${ }^{35}$
\end{abstract}

Tal qual ocorre com a prescrição retroativa, no que se refere a situação jurídica mais gravosa gerada ao acusado, ocorre com a prescrição antecipada. Assim, para aqueles que defendem a aplicação desta modalidade de prescrição, ela também poderá ser aplicada aos fatos ocorridos antes da entrada em vigor da Lei no $12.234 / 2010$, tendo em vista que como verificado no estudo realizado no capítulo 2 deste estudo a base para a aplicação da prescrição antecipada decorre do cálculo da prescrição retroativa utilizada de modo hipotético.

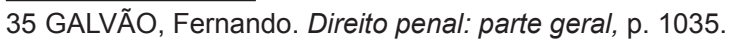




\section{PRESCRIÇÃOANTECIPADA EA GESTÃO DAJUSTIÇA}

Como é cediço, a prescrição antecipada se tornou matéria pacífica para os Tribunais após a edição da Súmula no 438 do STJ. Mas, para os operadores vanguardistas do direito não se trata de matéria pacificada, uma vez que deixar processos criminais ativos que jamais atingirão sua finalidade é emperrar o judiciário desnecessariamente.

Diante desta inquietação doutrinária e, também, jurisprudencial alguns questionamentos vêm à tona, quais sejam: Quais as consequências da (de)mora nas prestações jurisdicionais? Qual a relação do instituto da prescrição antecipada e a política judiciária? Quem se beneficia deste instituto? Quais os benefícios gerados ao Judiciário com a aplicação dele?

Para tanto, começa-se a refletir do ponto de vista da eficácia. Tem-se por premissa que "um processo penal que desde logo se apresente como despido das condições de possibilidade de gerar pena alguma é inconcebível", ${ }^{36}$ posto que seja capaz apenas de gerar pilhas de papéis que para nada servirão, tirando do judiciário tempo para a análise de causas que merecem ser assistidas com maior cautela.

Atualmente, está em pauta a questão da crise do Judiciário que nada mais é que um disfarce para se chegar ao real problema. Em verdade, constata-se que não é a crise do judiciário, mas sim a crise dos três poderes, que não se resolve em inflamados discursos, nem em questões judiciais, mas com uma questão de gestão.

No que tange ao Judiciário, que faz parte deste estudo, verifica-se que os aspectos considerados mais relevantes à Administração da Justiça são: a garantia do acesso à Justiça e o atendimento das demandas judiciais com eficácia em um prazo razoável.

No entanto, o que se observa é uma lentidão generalizada dos processos judiciais, em matéria criminal, é praticamente um 'crime' contra aquele que aguarda seu julgamento.

36 LOPES JR. Aury. Direito processual penal e sua conformidade constitucional, p.30. 
Não restam dúvidas que todo jurisdicionado tem direito de um processo que se resolva dentro de um prazo razoável, visto que as consequências são devastadoras para aquele que espera.

Nos processos criminais, como já estudado nos itens anteriores, muitas são as consequências, que, inclusive, ferem princípios constitucionais máximos como a dignidade da pessoa humana e o processo penal no prazo razoável.

Além do mais, tal crise não gera apenas consequências para o acusado, mas também para o próprio Poder Judiciário que fica com sua imagem ferida perante seus jurisdicionados, os quais preferem resolver suas questões, muitas vezes, de maneira ilegal, gerando inúmeros conflitos dentro da sociedade. Nesse sentido, espera-se menos formalismo e maior aproximação entre o judiciário e os cidadãos, uma vez que há necessidade de uma Justiça diferenciada e efetiva, buscando-se de tal modo soluções estruturais para que se alcance um Poder Judiciário almejado.

Dentro dessas soluções estruturais, vislumbra-se a aplicação da prescrição antecipada, visto que "a maior solução compensatória para a violação do direito à duração razoável do processo é a extinção da punibilidade". ${ }^{37}$

Não assiste razão em deixar processos inúteis em tramitação, visto que se verifica que em nada ajudará na aplicação do direito, nem ao alcance da Justiça que se busca.

A política judiciária e o instituto da prescrição antecipada estão intimamente ligados, ao passo que ambos buscam prestar uma solução à contenda de maneira eficiente.

Quanto aos benefícios gerados pela aplicação da prescrição antecipada, tem-se a liberação de serventuários da justiça e de tempo para que os processos carecedores de uma maior análise a tenham. Dentre outros, como a "agilidade" nas prestações jurisdicionais e o desafogamento dos cartórios judiciais e gabinetes.

Dessa forma, verifica-se que os pontos aqui definidos como essenciais entre a gestão judiciária e a prescrição antecipada, levam a entender que não há sentido algum manter em

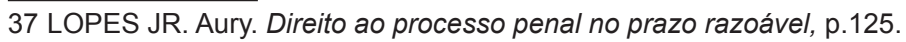


vigor uma Súmula que, ao invés de auxiliar o Judiciário na busca de soluções plausíveis às demandas e em prazos razoáveis, faz a justiça brasileira retroagir a tal ponto que não consegue superar seus obstáculos e volta ao período medieval, penalizando seus jurisdicionados por meio do calvário do processo penal.

\section{CONCLUSÃO}

Indicadas as premissas orientadoras deste artigo, a partir de levantamento bibliográfico, e reproduzidas as impressões e indicações consideradas relevantes, necessária se faz a síntese das ideias apresentadas e a exposição das conclusões do presente estudo.

Do estudo, depreende-se que o STJ ao editar a Súmula $n^{\circ}$ 438 acabou por consagrar, nesta área, parte da crise do judiciário, visto que, com o entendimento firmado na mencionada súmula, acaba por deixar em trâmite durante anos processos inúteis que jamais atingiram o fim a que se destinam.

Considerando que de nada adianta manter nos cartórios e gabinetes do judiciário brasileiro processos que ao chegar no seu auge terão a punibilidade extinta pela ocorrência da prescrição em razão da morosidade que se envolve o judiciário, muitos juízes de primeiro grau, bem como promotores de justiça e até mesmo certos tribunais mais vanguardistas aceitam a existência do instituto e sua aplicabilidade como meio de melhorar a efetividade da justiça na prestação da tutela jurisdicional.

Percebe-se, ainda, que os processos criminais são utilizados como métodos punitivos, sendo eles uma forma de estigmatização do indivíduo acusado, que ao longo do processamento do feito será subjulgado pela sociedade por integrar o polo passivo de uma demanda criminal, situação que só se findará com o julgamento final do processo que há muito levara anos e mais anos para se chegar a uma sentença de extinção da punibilidade pela ocorrência da prescrição propriamente dita, nos termos do art. 109, do CP.

Em suma, conclui-se que a postura tomada pelo STJ por meio da Súmula no 438 , que por vezes parece incoerente, nada 
mais é que uma postura tomada com o real objetivo de punir o acusado por meio de um longo processo penal. Ainda que essa postura se revista de legalidade, respaldando-se nas brechas da lei penal e processual penal, observa-se que ela afronta os princípios elementares do Estado democrático de direito, que são: o princípio da dignidade da pessoa humana, do devido processo legal e do processo penal no prazo razoável, consagrados na CRFB de 1988. Assim, a efetivação prática do reconhecimento da prescrição antecipada e até mesmo sua regulamentação pelo legislativo, se fazem necessários, tendo em vista que a postura tomada pelo Superior Tribunal de Justiça acerca do tema, ainda que não vinculante, por vezes torna inviabilizada a aplicação dessa modalidade prescricional, deixando a cargo dos tribunais a interpretação do posicionamento adotado pela Corte para cada aspecto decidido até a ulterior regulamentação do assunto pelo legislador ou decisão da Suprema Corte.

\section{REFERÊNCIAS}

ALMEIDA JUNIOR, João Mendes de. O processo criminal brasileiro. 3 ed. Rio de Janeiro: Batista de Souza, 1920

BRANDÃO, Edílson Aparecido. Prescrição em perspectiva. São Paulo: Revista dos Tribunais, 1994.

COUTINHO, Jacinto Nelson de Miranda. A lide e o conteúdo do processo penal. Curitiba: Juruá: 1998.

DOTTI, René Ariel. Curso de direito penal. 3 ed. São Paulo: Revista dos Tribunais, 2010.

GALVÃO, Fernando. Direito penal: parte geral. 4 ed. Rio de Janeiro: Lumen Juris, 2011.

JAWSNICKER, Francisco Afonso. Prescrição penal antecipada. 2 ed. Curitiba: Juruá Editora, 2008.

JESUS, Damásio Evangelista de. Prescrição penal. 13 ed. São Paulo: Saraiva, 1999.

SILVA, José Afonso da.Curso de direito constitucional positivo. 28. ed. São Paulo: Malheiros Editores, 2007. 
LOPES JR. Aury. Direito ao processo penal no prazo razoável. Rio de Janeiro: Lumen Juris, 2009.

LOPES JR. Aury. Direito processual penal e sua conformidade constitucional. v.

1. 7 ed. Rio de Janeiro: Lumen Juris, 2011.

MACHADO, Fábio Guedes de Paula. Prescrição penal: prescrição funcionalista. São Paulo: Revista dos Tribunais, 2000.

MORAIS, Alexandre de. Constituição do brasil interpretada e legislação constitucional. São Paulo: Atlas, 2002.

NUNES, Ricardo Pieri. Considerações em abona do reconhecimento antecipado da prescrição retroativa.v. 10, n. 119, São Paulo: Instituto Brasileiro de Ciências Criminais, 2002.

OLIVEIRA, Eugênio Pacelli de. Curso de processo penal. 11 ed. Rio de Janeiro: Lumen Juris, 2009.

SERPA, Juliano. A prescrição penal antecipada como causa da extinção da punibilidade no direito brasileiro. v. 15. n. 21. Florianópolis: Revista da ESMESC, 2008.

SOUZA, Renée. Prescrição virtual ou antecipada. v. 1. n. 5. Brasília: Revista Prática Jurídica, 2002.

ZAFFARONI, Eugênio Raúl. Direito penal brasileiro: teoria geral do direito penal. v. 1.2 ed. Rio de Janeiro: Revan, 2003.

BRASIL. Constituição (1988). Constituição da república federativa do brasil. Brasília, DF: Senado, 1988.

BRASIL. Lei no 12.243 (2010). Brasília/ DF: Senado, 2010.

BRASIL. Código de processo penal. Lei no Decreto-lei no 3.689, de 3 de outubro de 1941. Rio de Janeiro/RJ: Senado, 1941

BRASIL. Superior Tribunal de Justiça. Recurso em Habeas Corpus n. 8274 ES 1999/0004613-7. Rel. Des. Edson Vidigal, j. 13 de setembro de 1999.

BRASIL. Tribunal Regional Federal da 4a Região. Recurso em Sentido Estrito 199.70.01.008573/5. Rel. Des. Wolkmer de Castilho, j. 07 de outubro de 2002.

Artigo recebido em 12/08/2015

Artigo aprovado em 27/08/2015 